\title{
Low glucose-induced ghrelin secretion is mediated by an ATP-sensitive potassium channel
}

\author{
Manami Oya, Tetsuya Kitaguchi ${ }^{1,2}$, Kazuki Harada, Rika Numano ${ }^{3}$, Takahiro Sato ${ }^{4}$, \\ Masayasu Kojima ${ }^{4}$ and Takashi Tsuboi
}

Department of Life Sciences, Graduate School of Arts and Sciences, The University of Tokyo, 3-8-1 Komaba, Meguro, Tokyo 153-8902, Japan

${ }^{1}$ Cell Signaling Group, WASEDA Bioscience Research Institute in Singapore (WABIOS), 11 Biopolis Way, \#05-02 Helios, Singapore 138667, Singapore

${ }^{2}$ Organization for University Research Initiatives, Waseda University, \#304, Block 120-4,

513 Wasedatsurumaki-cho, Shinjuku-ku, Tokyo 162-0041, Japan

${ }^{3}$ Department of Environmental and Life Sciences, Electronics-Inspired Interdisciplinary Research Institute (EIIRIS),

Toyohashi University of Technology, 1-1 Hibarigaoka, Tennpaku-cho, Toyohashi, Aichi 441-8580, Japan

${ }^{4}$ Molecular Genetics, Institute of Life Sciences, Kurume University, 1-1 Hyakunen Kohen, Kurume,

Fukuoka 839-0864, Japan

\author{
Correspondence \\ should be addressed \\ to T Tsuboi \\ Email \\ takatsuboi@ \\ bio.c.u-tokyo.ac.jp
}

\begin{abstract}
Ghrelin is synthesized in X/A-like cells of the gastric mucosa, which plays an important role in the regulation of energy homeostasis. Although ghrelin secretion is known to be induced by neurotransmitters or hormones or by nutrient sensing in the ghrelin-secreting cells themselves, the mechanism of ghrelin secretion is not clearly understood. In the present study, we found that changing the extracellular glucose concentration from elevated $(25 \mathrm{mM})$ to optimal $(10 \mathrm{mM})$ caused an increase in the intracellular $\mathrm{Ca}^{2+}$ concentration $\left(\left[\mathrm{Ca}^{2+}\right]_{\mathrm{i}}\right)$ in ghrelin-secreting mouse ghrelinoma 3-1 (MGN3-1) cells $(n=32, P<0.01)$, whereas changing the glucose concentration from elevated to lowered $(5$ or $1 \mathrm{mM})$ had little effect on $\left[\mathrm{Ca}^{2+}\right]_{i}$ increase. Overexpression of a closed form of an ATP-sensitive $\mathrm{K}^{+}\left(\mathrm{K}_{\text {ATP }}\right)$ channel mutant suppressed the $10 \mathrm{mM}$ glucose-induced $\left[\mathrm{Ca}^{2+}\right]_{\mathrm{i}}$ increase $(n=8, P<0.01)$ and exocytotic events ( $n=6, P<0.01$ ). We also found that a low concentration of a $K_{\text {ATP }}$ channel opener, diazoxide, with $25 \mathrm{mM}$ glucose induced $\left[\mathrm{Ca}^{2+}\right]_{i}$ increase $(n=23, P<0.01)$ and ghrelin secretion ( $n \geq 3, P<0.05)$. In contrast, the application of a low concentration of a $K_{\text {ATP }}$ channel blocker, tolbutamide, significantly induced $\left[\mathrm{Ca}^{2+}\right]_{i}$ increase $(n=15, P<0.01)$ and ghrelin secretion ( $n \geq 3, P<0.05)$ under $5 \mathrm{mM}$ glucose. Furthermore, the application of voltage-dependent $\mathrm{Ca}^{2+}$ channel inhibitors suppressed the $10 \mathrm{mM}$ glucose-induced $\left[\mathrm{Ca}^{2+}\right]_{\mathrm{i}}$ increase $(n \geq 26, P<0.01)$ and ghrelin secretion $(n \geq 5, P<0.05)$. These findings suggest that $\mathrm{K}_{\mathrm{ATP}}$ and voltage-dependent $\mathrm{Ca}^{2+}$ channels are involved in glucose-dependent ghrelin secretion in MGN3-1 cells.
\end{abstract}

\section{Key Words}

- ATP-sensitive potassium channel

- calcium channel

- exocytosis

- ghrelin

- glucose

- total internal reflection fluorescence microscopy

\section{Introduction}

Ghrelin, a stomach-derived 28 amino acid peptide hormone, is synthesized and released from X/A-like endocrine cells of gastric mucosa (Kojima et al. 1999).
Ghrelin activates growth hormone (GH) secretagogue receptors that are expressed in agouti-related peptide/ neuropeptide Y-expressing hypothalamic neurons, which 
results in an increase in food intake (Kamegai et al. 2001, Nakazato et al. 2001). Ghrelin also regulates energy balance by promoting weight gain and adiposity (Tschop et al. 2000, Nakazato et al. 2001, Theander-Carrillo et al. 2006). Although the actions of ghrelin have been investigated intensively by several groups (Masuda et al. 2000, Takaya et al. 2000, Tschop et al. 2000, Kamegai et al. 2001, Nakazato et al. 2001, Nagaya \& Kangawa 2003, Nagaya et al. 2006, Theander-Carrillo et al. 2006), the mechanism of ghrelin secretion from the ghrelin-secreting $\mathrm{X} / \mathrm{A}$-like cells has not yet been elucidated.

Ghrelin-secreting cells are closed-type enteroendocrine cells that do not contact the gastric lumen and are not regulated directly by nutrients that are present in the stomach. However, recent studies have demonstrated that ingested proteins and lipids, which are absorbed in the small intestine, lower the plasma ghrelin concentration (Tschop et al. 2000, Williams et al. 2003, Foster-Schubert et al. 2008). Therefore, ghrelin secretion might be regulated by hormonal, neuronal, and metabolite signals that arise from nutrient sensing and absorption in the intestine. In fact, in support of this view, recent studies have shown that nutrients (i.e., fatty acids and glucose) and hormones (i.e., insulin and oxytocin) regulate ghrelin secretion in fluorescence-activated cell sorting-separated primary mouse ghrelin cells and ghrelinoma cell lines (i.e., SG-1, PG-1, and mouse ghrelinoma 3-1 (MGN3-1)) (Janssen et al. 2012, Sakata et al. 2012).

Insulin and glucagon are also peptide hormones, and their secretions from pancreatic $\alpha$ and $\beta$ cells respectively are mediated by nutrients, especially glucose. Although pancreatic $\beta$ cells secrete insulin when the plasma glucose concentration is high, pancreatic $\alpha$ cells secrete glucagon in response to a decrease in the plasma glucose concentration (MacDonald et al. 2007), which is similar to ghrelin secretion from the ghrelin-secreting X/A-like cells. Both pancreatic $\alpha$ and $\beta$ cells express ATP-sensitive $\mathrm{K}^{+}\left(\mathrm{K}_{\mathrm{ATP}}\right)$ channels composed of a sulfonylurea receptor 1 and an inward rectifier potassium channel (Kir6.2) (Suzuki et al. 1997, 1999), and it has been shown that both insulin and glucagon secretion are regulated by $K_{A T P}$ channels (McTaggart et al. 2010). Interestingly, voltage-dependent $\mathrm{Ca}^{2+}$ channels are expressed in pancreatic $\alpha$ and $\beta$ cells in different combinations. A previous paper showed that a blocker of the L-type $\mathrm{Ca}^{2+}$ channel inhibited insulin secretion from pancreatic $\beta$ cells, and a blocker of the $\mathrm{N}$-type and T-type $\mathrm{Ca}^{2+}$ channels inhibited glucagon secretion from pancreatic $\alpha$ cells (Quesada et al. 2008). Thus, we hypothesize that the $\mathrm{K}_{\mathrm{ATP}}$ channels and the voltage-dependent $\mathrm{Ca}^{2+}$ channels might be involved in the regulation of glucose-dependent ghrelin secretion from ghrelin-secreting cells, which is similar to the regulation of glucagon secretion in pancreatic $\alpha$ cells.

In the present study, we examined the role of $K_{\text {ATP }}$ channels and the voltage-dependent $\mathrm{Ca}^{2+}$ channels in ghrelin secretion from MGN3-1 cells, which is the first cell line from a gastric ghrelin-producing cell tumor derived from ghrelin-promoter simian virus 40 T-antigen transgenic mice (Iwakura et al. 2010, 2011), and we evaluated how $\mathrm{K}_{\mathrm{ATP}}$ channels and voltage-dependent $\mathrm{Ca}^{2+}$ channels contribute to glucose-dependent ghrelin secretion.

\section{Materials and methods}

\section{Chemicals}

D-glucose, diazoxide (DZ), diltiazem, and EGTA were purchased from Wako Pure Chemicals (Osaka, Japan). Fluo3 acetoxymethylester (Fluo3-AM), NNC55-0396, tolbutamide (TB), and $\omega$-conotoxin ( $\omega$-CgTX) GVIA were purchased from Sigma-Aldrich.

\section{Plasmid construction}

Mouse Kir6.2 was amplified from a mouse brain cDNA by PCR. The cDNA fragment of Kir6.2 was inserted into EcoRI/BamHI sites of the pmCherry-N1 vector (Oya et al. 2013a). The dominant-negative mutation (G132S) in the selectivity filter of Kir6.2 (Koster et al. 2002) was created by sequential PCR (Kir6.2DN-mCherry). Expression vectors that encoded Venus-tagged brain-derived neurotrophic factor (BDNF-Venus) were constructed as described previously (Aoki et al. 2010). All of the DNA sequences were validated by sequencing.

\section{Cell culture and transfection}

The ghrelin-producing cell line MGN3-1 cells from a gastric tumor derived from ghrelin-promoter simian virus 40 T-antigen transgenic mice (kindly provided by Dr Hiroshi Iwakura, Kyoto University, Kyoto, Japan) were cultured in DMEM (Life Technologies) supplemented with $10 \%$ fetal bovine serum, $100 \mathrm{U} / \mathrm{ml}$ penicillin, and $100 \mu \mathrm{g} / \mathrm{ml}$ streptomycin at $37^{\circ} \mathrm{C}$ in $5 \% \mathrm{CO}_{2}$ (Iwakura et al. 2010, 2011). To image ghrelin secretion, MGN3-1 cells were plated onto poly-L-lysine-coated coverslips and transfected with $1.5 \mu \mathrm{g}$ BDNF-Venus and $1.5 \mu \mathrm{g}$ Kir6.2 DN-mCherry expression vectors using $6 \mu$ Lipofectamine 2000 (Life Technologies) and $200 \mu$ l Opti-MEM (Life Technologies). Transfected cells were cultured in DMEM for

Published by Bioscientifica Ltd. 
2 days until imaging. Under the present experimental conditions, the transfection efficiency was about $25 \%$ for double transfection and about $50 \%$ for single transfection.

\section{Visualization of intracellular $\mathrm{Ca}^{2+}$ dynamics}

Changes in the intracellular $\mathrm{Ca}^{2+}$ concentration $\left(\left[\mathrm{Ca}^{2+}\right]_{\mathrm{i}}\right)$ were measured using Fluo3-AM. MGN3-1 cells and Kir6.2DN-mCherry-expressing MGN3-1 cells on coverslips were loaded with $2.5 \mu \mathrm{M}$ Fluo3-AM in modified Ringer's buffer $\left(140 \mathrm{mM} \mathrm{NaCl}, 3.6 \mathrm{mM} \mathrm{KCl}, 0.5 \mathrm{mM} \mathrm{NaH}{ }_{2} \mathrm{PO}_{4}\right.$, $0.5 \mathrm{mM} \mathrm{MgSO}_{4}, 1.5 \mathrm{mM} \mathrm{CaCl}, 10 \mathrm{mM}$ HEPES, $2 \mathrm{mM}$ $\mathrm{NaHCO}_{3}$, and $5 \mathrm{mM}$ glucose, $\mathrm{pH} 7.4$ ) for $20 \mathrm{~min}$ at $37^{\circ} \mathrm{C}$.

The cells were then washed two times before imaging. Imaging of the MGN3-1 cells was performed in Ringer's buffer containing $25 \mathrm{mM}$ glucose. Glucose stimulation was achieved by perfusion with Ringer's buffer containing $1,5,10,15$, or $25 \mathrm{mM}$ glucose. Cells were then mounted in a chamber and placed on the stage of an Olympus IX-71 inverted microscope (Olympus). Fluo3-AM-loaded cells were excited at $480 \mathrm{~nm}$ at $5 \mathrm{~s}$ intervals with a xenon lamp, and emission signals at $515 \mathrm{~nm}$ were detected with an electron multiplying charge-coupled device (EM-CCD) camera (Evolve, Photometrics, Tucson, AZ, USA).

\section{Immunocytochemistry}

After 2 days of transfection with BDNF-Venus, the MGN31 cells were washed in PBS and fixed with $4 \%$ paraformaldehyde for $20 \mathrm{~min}$ at room temperature. The cells were then sequentially reacted with the anti-N-terminal rabbit acyl-ghrelin antibody (1:100 000 dilution, produced by Prof. M K, Kurume University, Fukuoka, Japan) and the anti-rabbit Alexa568-conjugted secondary antibody (1:3000 dilution, Life Technologies). Confocal images were obtained by a Nipkow-disk confocal scanner (CSU10, Yokogawa, Tokyo, Japan) equipped with an EM-CCD camera (C9100-02, Hamamatsu Photonics, Hamamatsu, Japan) and controlled by MetaMorph Software version 7.7 (Molecular Devices, Sunnyvale, CA, USA).

\section{Total internal reflection fluorescence imaging}

To observe the release of BDNF-Venus at the single-vesicle level, we used a total internal reflection fluorescence (TIRF) microscope similar to those described previously (Mori et al. 2011, Oya et al. 2011, 2013a,b, Sato et al. 2012, Kitaguchi et al. 2013). Briefly, a high numerical aperture objective lens (CFI Apochromat TIRF, 100×, NA=1.49, Nikon, Tokyo, Japan) was mounted on an inverted microscope (Ti-E-Perfect focus system, Nikon), and incident light for total internal reflection illumination was introduced from the high numerical aperture objective lens through a single-mode optical fiber and two illumination lenses (TI-TIRF, Nikon). To observe the BDNF-Venus fluorescence images, we used an optically pumped semiconductor $488 \mathrm{~nm}$ laser (Sapphire 488LP, $30 \mathrm{~mW}$, Coherent, Santa Clara, CA, USA) for total internal fluorescence illumination and a band-pass filter (HQ535/30m, Chroma, Bellows Falls, VT, USA) as an emission filter. The laser beam was passed through an electromagnetically driven shutter (TI-TIRF, Nikon), and the shutter was opened synchronously with EM-CCD camera (iXon, Andor, Belfast, UK) exposure, which was controlled by either NIS-Elements (Nikon) or MetaMorph Software. Images were acquired every $500 \mathrm{~ms}$. Imaging was performed in Ringer's buffer. Glucose stimulation was achieved by perfusion with Ringer's buffer containing 1, 5 , 10,15 , or $25 \mathrm{mM}$ glucose. To distinguish between fusion events and retreated vesicles, we focused on fluorescence changes just before the disappearance of fluorescent signals. A fusion event was demonstrated by a rapid transient increase in fluorescence intensity (to peak intensity almost two times greater than the original fluorescence intensity within $1 \mathrm{~s}$ ). By contrast, vesicle movements were shown by the fluorescence intensity gradually decreasing to the background level, as described previously (Tsuboi et al. 2006). The number of fusion events during a $20 \mathrm{~min}$ period was counted manually.

\section{Measurement of ghrelin secretion}

MGN3-1 cells were plated at a density of $3.0 \times 10^{5}$ cells/well in six-well plates and cultured in DMEM containing $25 \mathrm{mM}$ glucose for 2 days. Before treatment, cells were switched to Ringer's buffer. The cells were incubated for $1 \mathrm{~h}$ in Ringer's buffer that contained various concentrations of glucose: 5 or $25 \mathrm{mM}$ glucose plus $1 \mu \mathrm{M}$ TB or $1 \mu \mathrm{M} \mathrm{DZ}$; or $10 \mathrm{mM}$ glucose plus $1 \mu \mathrm{M}$ diltiazem, $1 \mu \mathrm{M} \omega$-CgTX, $1 \mu \mathrm{M}$ NNC55-0396, or 2 mM EGTA. The amount of secreted acyl- or desacyl-ghrelin into the Ringer's buffer was measured by an ELISA kit specific for acyl- or desacyl-ghrelin (SCETI, Tokyo, Japan). Data are reported as means \pm s.E.M.

\section{Statistical analysis}

Data are reported as means \pm s.e.m. Means were compared by the Student's $t$-test (for two groups) or by ANOVA

Published by Bioscientifica Ltd 
followed by a Dunnett's test using GraphPad Prism Software (GraphPad Software, La Jolla, CA, USA).

\section{Results}

\section{$\mathrm{K}_{\text {ATP }}$ channels are involved in low glucose-induced} $\mathrm{Ca}^{2+}$ increase

To examine the effect of glucose on the $\left[\mathrm{Ca}^{2+}\right]_{\mathrm{i}}$ changes in ghrelin-secreting cells in vitro, we used a novel ghrelinproducing cell line, MGN3-1 cells, from a gastric ghrelinproducing cell tumor derived from ghrelin-promoter simian virus $40 \mathrm{~T}$-antigen transgenic mice (Iwakura et al. $2010,2011)$. When the glucose concentration was lowered from $25 \mathrm{mM}$ to either 10 or $15 \mathrm{mM}$, ghrelin-secreting MGN3-1 cells displayed an increase in $\left[\mathrm{Ca}^{2+}\right]_{\mathrm{i}}$ (Fig. 1A and B; G10: $125.7 \pm 3.9 \%, n=32$ cells, $P<0.01$ and G15: $114.9 \pm 3.8 \%, n=23$ cells, $P<0.05)$. Meanwhile, lowering the glucose concentration from $25 \mathrm{mM}$ to either 1 or $5 \mathrm{mM}$ had little effect on the $\left[\mathrm{Ca}^{2+}\right]_{\mathrm{i}}$, and maintaining the glucose concentration at $25 \mathrm{mM}$ also showed little change (Fig. $1 \mathrm{~A}$ and B; G1: $107.1 \pm 1.3 \%, n=41$ cells, $P=0.75$; G5: $113.5 \pm 2.8 \%, n=24$ cells, $P=0.06$; and G25: $103.5 \pm 1.1 \%$, $n=25$ cells).

Pancreatic $\alpha$ cells secrete glucagon in response to a decrease in glucose concentration, and they express $\mathrm{K}_{\mathrm{ATP}}$ channels to enable glucagon secretion (Gromada et al. 2007). To examine whether $K_{\text {ATP }}$ channels were also involved in ghrelin secretion from X/A-like endocrine cells, we overexpressed a dominant-negative form of the $\mathrm{K}_{\mathrm{ATP}}$ channel subunit Kir6.2 (Kir6.2DN, substitution of
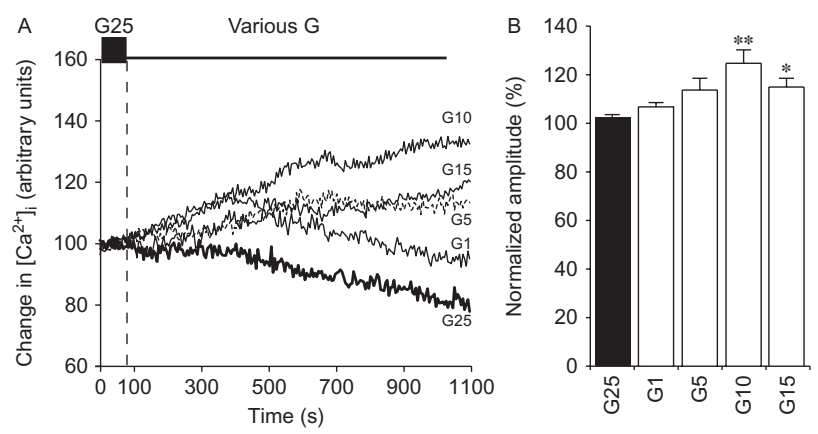

\section{Figure 1}

Effect of glucose on $\left[\mathrm{Ca}^{2+}\right]_{i}$ changes in MGN3-1. (A) Typical time course showing $\left[\mathrm{Ca}^{2+}\right]_{i}$ changes during the application of various concentrations of glucose to MGN3-1 cells. Stimuli were applied at the times indicated by the dotted line. Basal fluorescence intensity was normalized to 100 . (B) Lowering the glucose concentration caused an increase in $\left[\mathrm{Ca}^{2+}\right]_{\mathrm{i}}$. Normalized amplitude was calculated from the peak amplitude induced by various concentrations of glucose. Data are shown as means \pm s.E.M. ( $n=$ at least 23 cells in each condition). ${ }^{*} P<0.05$ and $* * P<0.01$.
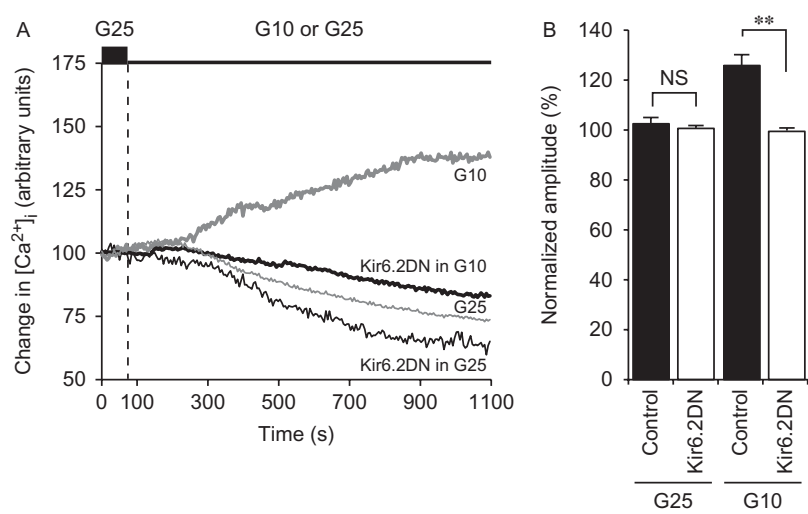

\section{Figure 2}

The $K_{\text {ATP }}$ channel is involved in low glucose-induced $\left[\mathrm{Ca}^{2+}\right]_{i}$ increase. (A) Typical time course showing $\left[\mathrm{Ca}^{2+}\right]_{i}$ during the application of either 10 or $25 \mathrm{mM}$ glucose to MGN3-1 cells that expressed a dominant-negative form of the $\mathrm{K}_{\text {ATP }}$ channel subunit Kir6.2 (Kir6.2DN). Stimuli were applied at the times indicated by the dotted line. Basal fluorescence intensity was normalized to 100. (B) Lowering the glucose concentration had little effect on the $\left[\mathrm{Ca}^{2+}\right]_{i}$ increase in the MGN3-1 cells that expressed Kir6.2DN. Normalized amplitude was calculated from the peak amplitude induced by the glucose concentration change. Data are shown as means \pm S.E.M. ( $n=$ at least eight cells in each condition). NS, not significant. $* * P<0.01$.

glycine with serine at position 132; Seino et al. 2000) in MGN3-1 cells and monitored the effect on low glucoseinduced $\left[\mathrm{Ca}^{2+}\right]_{\mathrm{i}}$ changes (Fig. $2 \mathrm{~A}$ ). We found that the increase in $\left[\mathrm{Ca}^{2+}\right]_{i}$ that was caused by lowering the extracellular glucose concentration was suppressed in Kir6.2DN-expressing MGN3-1 cells (Fig. 2B; control in G10: $125.7 \pm 3.9 \%, n=32$ cells and Kir6.2DN in G10: $99.7 \pm 2.1 \%, n=8$ cells, $P<0.01$ ). These results suggest that lowering extracellular glucose concentration increases $\left[\mathrm{Ca}^{2+}\right]_{\mathrm{i}}$ via the $\mathrm{K}_{\mathrm{ATP}}$ channel-mediated pathway in MGN3-1 cells.

\section{Low glucose induces ghrelin secretion in MGN3-1 cells}

We observed the dynamics of single ghrelin exocytotic events in live MGN3-1 cells by TIRF microscopy. To visualize ghrelin secretion, we transfected fluorescent protein (FP)-tagged BDNF because FP-tagged BDNF (i.e., BDNF-Venus)-positive vesicles were shown to well co-localize with ghrelin-containing vesicles in MGN3-1 cells by immunocytochemistry (Fig. $3 \mathrm{~A} ; 75.6 \pm 4.8 \%, n=20$ cells). After lowering the extracellular glucose concentration, highly punctate BDNF-Venus fluorescent spots suddenly brightened and subsequently dimmed (Fig. 3B), which shows that ghrelin was secreted to the extracellular space. Similar to the $\left[\mathrm{Ca}^{2+}\right]_{\mathrm{i}}$ increase that is caused by lowering glucose, the number of BDNF-Venus exocytotic

Published by Bioscientifica Ltd. 
A
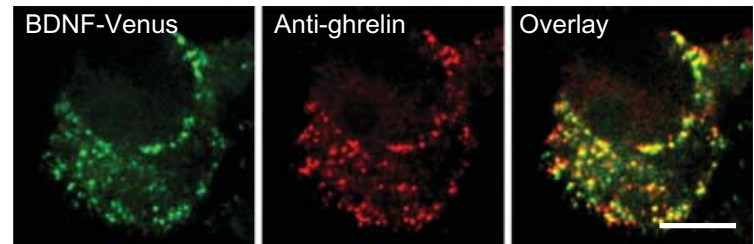

B
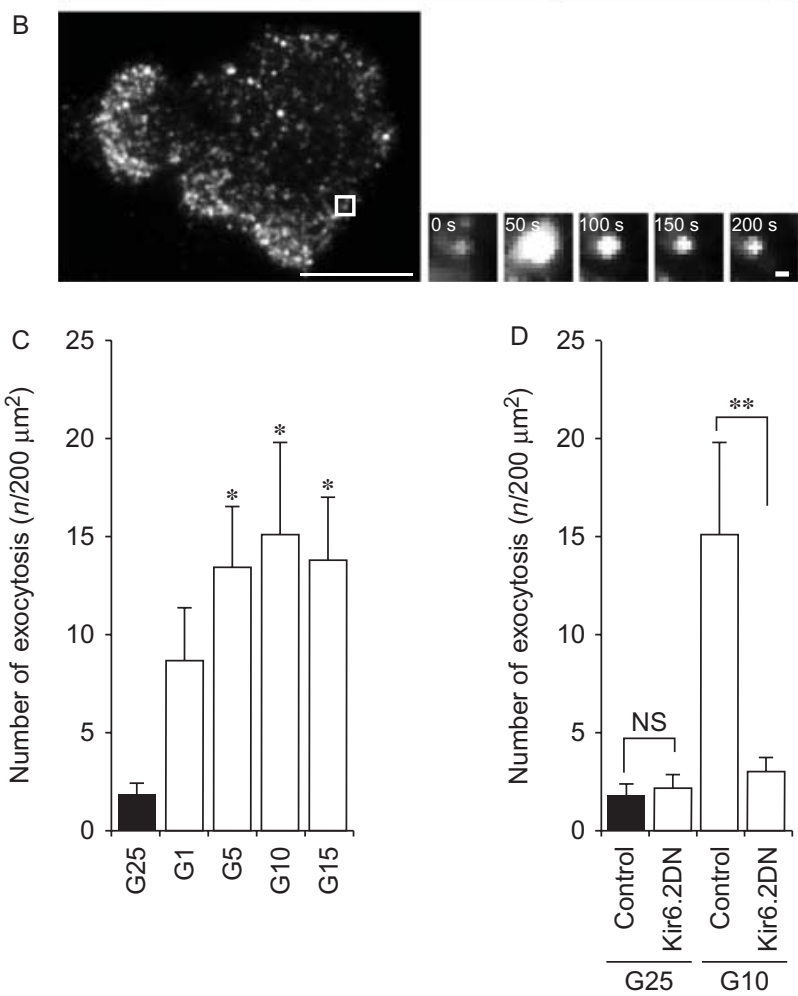

Figure 3

Effect of glucose on ghrelin exocytosis from MGN3-1 cells. (A) Typical confocal image of paraformaldehyde-fixed MGN3-1 cells showing the distribution of BDNF-Venus (green) and ghrelin (red). Scale bar $=10 \mu \mathrm{m}$. (B, left) Typical TIRF image of BDNF-Venus-expressing MGN3-1 cells. The position of the vesicle before exocytosis is outlined by a square. Scale bar = $10 \mu \mathrm{m}$. (B, right) Five sequential TIRF images showing exocytotic release of BDNF-Venus after the application of $10 \mathrm{mM}$ glucose. Scale bar $=1 \mu \mathrm{m}$. (C) The number of exocytotic events during the application of glucose at various concentrations. Data are shown as means \pm s.E.M. $(n=$ at least six cells in each condition). (D) The number of exocytotic events during the application of either 10 or 25 mM glucose to MGN3-1 cells that expressed Kir6.2DN. Data are shown as means \pm s.E.M. ( $n=$ at least six cells in each condition). NS, not significant. ${ }^{*} P<0.05$ and $* * P<0.01$.

events was increased by 5,10 , and $15 \mathrm{mM}$ glucose stimulation (Fig. 3C; G25: $1.9 \pm 0.5$ events $/ 200 \mu \mathrm{m}^{2}, n=8$ cells; G1: $8.6 \pm 2.9$ events $/ 200 \mu \mathrm{m}^{2}, n=8$ cells, $P=0.33$; G5: $13.5 \pm 3.1$ events $/ 200 \mu \mathrm{m}^{2}, n=7$ cells, $P<0.05 ; \mathrm{G} 10$ : $15.1 \pm 4.7$ events $/ 200 \mu \mathrm{m}^{2}, n=7$ cells, $P<0.05$; and G15: $13.9 \pm 3.3$ events $/ 200 \mu \mathrm{m}^{2}, n=6$ cells, $\left.P<0.05\right)$. We next monitored exocytotic events in Kir6.2DN-expressing MGN3-1 cells and found that $10 \mathrm{mM}$ glucose-induced BDNF-Venus exocytotic events were significantly inhibited
(Fig. 3D; control in G10: $15.1 \pm 4.7$ events $/ 200 \mu \mathrm{m}^{2}$, $n=7$ cells and Kir6.2DN in G10: $2.9 \pm 0.8$ events $/ 200 \mu \mathrm{m}^{2}$, $n=6$ cells, $P<0.01$ ). Additionally, the amount of secreted ghrelin was measured by ELISA. Because there are two types of ghrelin (i.e., acyl- and desacyl-ghrelin) circulating in the blood, each of which show distinct functions (Kojima et al. 1999), we measured the amount of both acyl- and desacyl-ghrelin secreted. The amount of secreted acyl-ghrelin increased when low glucose stimulation was applied (Fig. 4, left panel; G25: $100.0 \pm 4.1 \%$, $n=5$ trials; G1: $146.2 \pm 16.1 \%, n=6$ trials, $P<0.05$; G5: $190.5 \pm 15.6 \%, n=6$ trials, $P<0.01$; G10: $210.6 \pm 6.0 \%$, $n=6$ trials, $P<0.01$; and G15: $229.1 \pm 11.1 \%, n=6$ trials, $P<0.01$ ), whereas the amount of secreted desacyl-ghrelin increased when the glucose concentration was lowered from 25 to $10 \mathrm{mM}$ or $15 \mathrm{mM}$ (Fig. 4, right panel; G25: $100.0 \pm 5.7 \%, n=6$ trials; G1: $103.4 \pm 10.5 \%, n=6$ trials, $P=0.99 ; \mathrm{G} 5: 157.0 \pm 19.8 \%, n=6$ trials, $P=0.26$; G10: $228.9 \pm 35.9 \%, n=6$ trials, $P<0.01$; and G15: 214.7 $\pm 29.1 \%, n=6$ trials, $P<0.01$ ). These results suggest that acyl- and desacyl-ghrelin secretion were induced in similar but slightly distinct manners. Together with our evidence that the $\left[\mathrm{Ca}^{2+}\right]_{i}$ increase by low glucose involves $\mathrm{K}_{\mathrm{ATP}}$ channels (Fig. 2), these results indicate that lowering the extracellular glucose concentration increases ghrelin secretion via a $\left[\mathrm{Ca}^{2+}\right]_{\mathrm{i}}$ increase by a $\mathrm{K}_{\mathrm{ATP}}$ channel-mediated pathway in MGN3-1 cells.
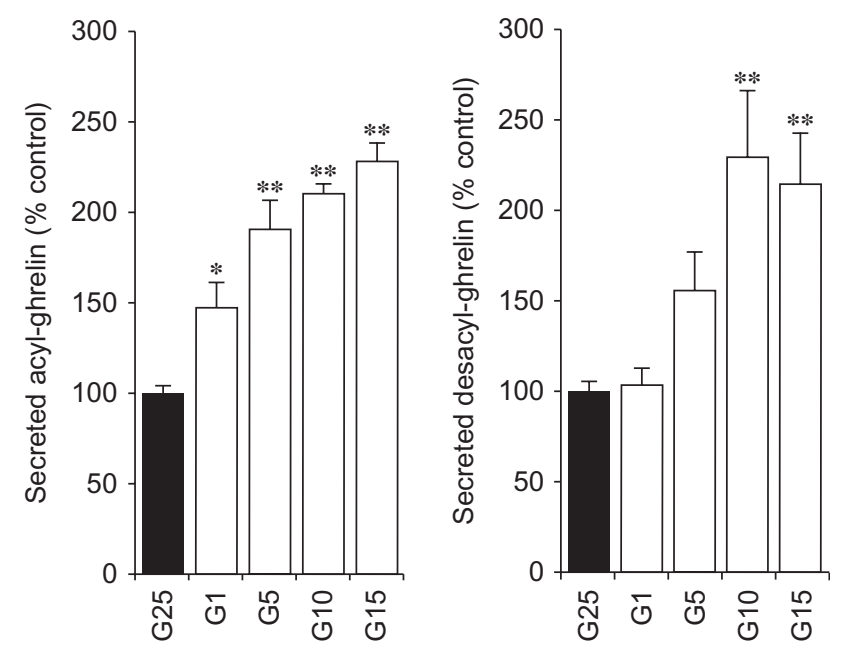

Figure 4

The amount of secreted acyl-ghrelin (left) and desacyl-ghrelin (right) after the application of various concentrations of glucose as measured by ELISA. Data are shown as means \pm S.E.M. ( $n=$ at least five trials in each condition). $\star P<0.05$ and $* * P<0.01$.

Published by Bioscientifica Ltd 

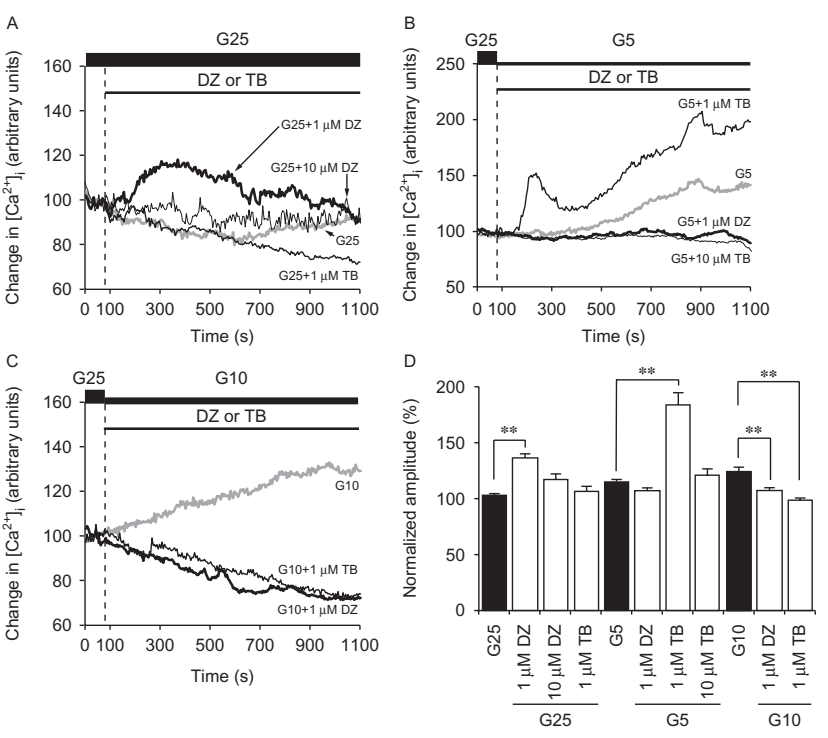

Figure 5

Effect of $\mathrm{K}_{\text {ATP }}$ channel opener and blocker on $\left[\mathrm{Ca}^{2+}\right]_{i}$ changes in MGN3-1 cells. Typical time course showing $\left[\mathrm{Ca}^{2+}\right]_{\mathrm{i}}$ changes during the application of either $25 \mathrm{mM}(\mathrm{A}), 5 \mathrm{mM}$ (B), or $10 \mathrm{mM}$ (C) glucose alone, with 1 or $10 \mu \mathrm{M}$ diazoxide (DZ), or with 1 or $10 \mu \mathrm{M}$ tolbutamide (TB) to MGN3-1 cells. Stimuli were applied at the times indicated by the dotted line. Basal fluorescence intensity was normalized to 100 . (D) The application of $1 \mu \mathrm{M}$ $\mathrm{DZ}$ with $25 \mathrm{mM}$ glucose induced a $\left[\mathrm{Ca}^{2+}\right]_{i}$ increase, whereas $1 \mu \mathrm{M}$ TB or $10 \mu \mathrm{M}$ DZ had little effect on $\left[\mathrm{Ca}^{2+}\right]_{\mathrm{i}}$. In contrast, $1 \mu \mathrm{M}$ TB with $5 \mathrm{mM}$ glucose significantly increased $\left[\mathrm{Ca}^{2+}\right]_{\mathrm{i}}$, whereas $1 \mu \mathrm{M} \mathrm{DZ}$ or $10 \mu \mathrm{M}$ TB with $5 \mathrm{mM}$ glucose had little effect on $\left[\mathrm{Ca}^{2+}\right]_{i}$. The application of either $1 \mu \mathrm{M} \mathrm{DZ}$ or $1 \mu \mathrm{M}$ TB with $10 \mathrm{mM}$ glucose decreased $\left[\mathrm{Ca}^{2+}\right]_{i}$. Normalized amplitude was calculated from the peak amplitude induced by various stimuli. Data are shown as means \pm s.E.M. ( $n=$ at least 13 cells in each condition). $* * P<0.01$.

\section{The modulation of $\mathrm{K}_{\text {ATP }}$ channel function affects glucose-induced ghrelin secretion}

We applied a $\mathrm{K}_{\mathrm{ATP}}$ channel opener or blocker (i.e., DZ or TB respectively) to modulate $\mathrm{K}_{\mathrm{ATP}}$ channel activity. We found that the application of $1 \mu \mathrm{M} \mathrm{DZ}$ with $25 \mathrm{mM}$ glucose induced $\left[\mathrm{Ca}^{2+}\right]_{\mathrm{i}}$ increase, whereas the application of $1 \mu \mathrm{M}$ TB with $25 \mathrm{mM}$ glucose had little effect on $\left[\mathrm{Ca}^{2+}\right]_{\mathrm{i}}$ change (Fig. 5A and D; G25: $103.5 \pm 1.1 \%, n=25$ cells; $1 \mu \mathrm{M} \mathrm{DZ}$ with G25: $137.3 \pm 3.8 \%, n=23$ cells, $P<0.01$; and $1 \mu \mathrm{M}$ TB with G25: $107.0 \pm 5.3 \%, n=17$ cells, $P=0.99)$. The application of $1 \mu \mathrm{M}$ TB with $5 \mathrm{mM}$ glucose to MGN3-1 cells significantly increased $\left[\mathrm{Ca}^{2+}\right]_{i}$, whereas the application of $1 \mu \mathrm{M}$ DZ with $5 \mathrm{mM}$ glucose induced little $\left[\mathrm{Ca}^{2+}\right]_{\mathrm{i}}$ change (Fig. 5B and D; G5: $116.4 \pm 1.6 \%, n=29$ cells; $1 \mu \mathrm{M}$ DZ with G5: $107.8 \pm 2.9 \%, n=17$ cells, $P=0.62$; and $1 \mu \mathrm{M}$ TB with G5: $185.0 \pm 10.9 \%, n=15$ cells, $P<0.01$ ). Although the application of $1 \mu \mathrm{M} \mathrm{DZ}$ with $25 \mathrm{mM}$ glucose or $1 \mu \mathrm{M}$ TB with $5 \mathrm{mM}$ glucose induced $\left[\mathrm{Ca}^{2+}\right]_{\mathrm{i}}$ increase, the application of a high concentration (i.e., $10 \mu \mathrm{M}$ ) of DZ or TB had little effect on $\left[\mathrm{Ca}^{2+}\right]_{\mathrm{i}}$ change (Fig. 5A and D; $10 \mu \mathrm{M}$ DZ with G25: $118.9 \pm 4.7 \%, n=13$ cells, $P=0.13$ and $10 \mu \mathrm{M}$ TB with G5: $122.8 \pm 5.5 \%, n=15$ cells, $P=0.90)$. Interestingly, the application of either $1 \mu \mathrm{M} \mathrm{DZ}$ or $1 \mu \mathrm{M} \mathrm{TB}$ with $10 \mathrm{mM}$ glucose decreased $\left[\mathrm{Ca}^{2+}\right]_{\mathrm{i}}$ (Fig. 5C and D; G10: $125.7 \pm 3.9 \%, n=32$ cells; $1 \mu \mathrm{M}$ DZ with G10: $108.8 \pm$ $3.0 \%, n=35$ cells, $P<0.01$; and $1 \mu \mathrm{M}$ TB with G10: $99.5 \pm$ $1.8 \%, n=30$ cells, $P<0.01)$. Furthermore, to examine the effect of the modulation of $\mathrm{K}_{\mathrm{ATP}}$ channel activity on ghrelin secretion, we measured the amount of both secreted acyl-ghrelin and secreted desacyl-ghrelin by ELISA. We found that the application of $1 \mu \mathrm{M} \mathrm{DZ}$ with $25 \mathrm{mM}$ glucose or $1 \mu \mathrm{M}$ TB with $5 \mathrm{mM}$ glucose significantly increased the amount of both acyl- and desacylghrelin (Fig. 6; acyl-ghrelin: G25: 99.0 $\pm 2.9 \%, n=17$ trials; $1 \mu \mathrm{M}$ DZ with G25: $141.5 \pm 25.8 \%, n=6$ trials, $P<0.05$; G5: $147.4 \pm 9.1 \%, n=9$ trials, $P<0.01 ; 1 \mu \mathrm{M}$ TB with $\mathrm{G} 5$ : 238.4 $\pm 60.0 \%, n=5$ trials, $P<0.05$ and desacyl-ghrelin: G25: $100.0 \pm 5.1 \%, n=21$ trials; $1 \mu \mathrm{M}$ DZ with G25: 129.4 $\pm 10.0 \%, n=3$ trials, $P<0.05$; G5: $163.7 \pm 16.3 \%$, $n=14$ trials, $P<0.01 ; 1 \mu \mathrm{M}$ TB with G5: $242.4 \pm 45.9 \%$, $n=3$ trials, $P<0.05)$, which is consistent with the $\left[\mathrm{Ca}^{2+}\right]_{\mathrm{i}}$ changes (Fig. 5). These results suggest that the extent of
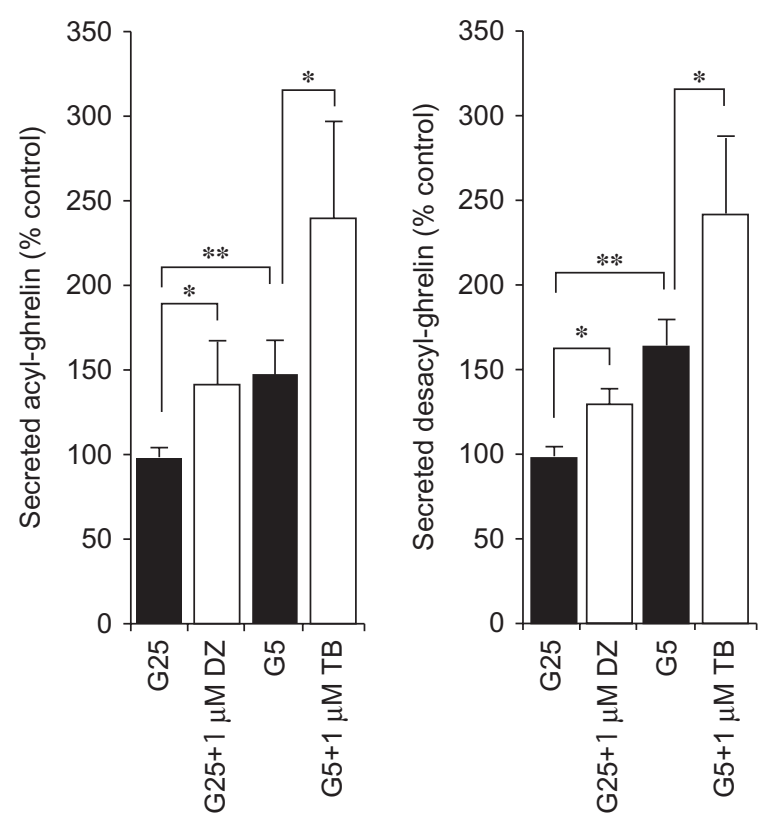

Figure 6

Effect of $K_{\text {ATP }}$ channel opener and blocker on ghrelin secretion from MGN31 cells. The amount of secreted acyl- (left) and desacyl-ghrelin (right) after the application of either 5 or $25 \mathrm{mM}$ glucose with $1 \mu \mathrm{M} \mathrm{DZ}$ and TB as measured by ELISA. Data are shown as means \pm s.E.M. $(n=$ at least three trials in each condition). ${ }^{*} P<0.05$ and $* * P<0.01$.

Published by Bioscientifica Ltd 
the $\mathrm{K}_{\text {ATP }}$ channel opening is involved in $\left[\mathrm{Ca}^{2+}\right]_{\mathrm{i}}$ increase and ghrelin secretion.

\section{Voltage-dependent $\mathrm{Ca}^{2+}$ channels are involved in ghrelin secretion from MGN3-1 cells}

We examined the $\left[\mathrm{Ca}^{2+}\right]_{i}$ effects of the inhibitors of either $\mathrm{L}-, \mathrm{N}-$, or T-type $\mathrm{Ca}^{2+}$ channels (i.e., diltiazem, $\omega$-CgTX, or NNC55-0396 respectively) on low glucose stimulation. The application of each inhibitor with $10 \mathrm{mM}$ glucose significantly suppressed the low glucose-induced $\left[\mathrm{Ca}^{2+}\right]_{\mathrm{i}}$ increase (Fig. 7A and B; G25: $103.5 \pm 1.1 \%, n=25$ cells; G10: $125.7 \pm 3.9 \%, n=32$ cells, $P<0.01 ; 1 \mu \mathrm{M}$ diltiazem with G10: $109.9 \pm 2.0 \%, n=26$ cells, $P<0.01 ; 1 \mu \mathrm{M}$ $\omega$-CgTX with G10: $100.3 \pm 1.8 \%, n=27$ cells, $P<0.01$; and $1 \mu \mathrm{M}$ NNC55-0396 with G10: $109.3 \pm 1.3 \%, n=26$ cells, $P<0.01)$. The application of EGTA to deplete the extracellular $\mathrm{Ca}^{2+}$ ions also significantly suppressed glucose-induced $\left[\mathrm{Ca}^{2+}\right]_{\mathrm{i}}$ responses (Fig. 7A and B; $2 \mathrm{mM}$ EGTA with G10: $98.7 \pm 0.5 \%, n=25$ cells, $P<0.01$ ). Consistent with the $\left[\mathrm{Ca}^{2+}\right]_{\mathrm{i}}$ increase, we found that the application of $1 \mu \mathrm{M}$ diltiazem, $1 \mu \mathrm{M} \omega$-CgTX, or $1 \mu \mathrm{M}$ NNC55-0396 with $10 \mathrm{mM}$ glucose suppressed the low glucose-dependent secretion of both acyl- and desacylghrelin (Fig. 7C; acyl-ghrelin: G25: 100.0 $\pm 3.0 \%, n=7$ trials; G10: $210.6 \pm 6.0 \%, n=6$ trials, $P<0.01 ; 1 \mu \mathrm{M}$ diltiazem with G10: $145.1 \pm 22.2 \%, n=6$ trials, $P<0.05$; $1 \mu \mathrm{M} \omega$-CgTX with G10: $105.5 \pm 14.7 \%, n=6$ trials, $P<0.01 ; 1 \mu \mathrm{M}$ NNC55-0396 with G10: $148.1 \pm 25.7 \%$, $n=6$ trials, $P<0.05$ and desacyl-ghrelin: G25: 101.1 $\pm 4.8 \%, n=11$ trials; G10: $228.9 \pm 35.9 \%, n=6$ trials, $P<0.01 ; 1 \mu \mathrm{M}$ diltiazem with G10: $100.3 \pm 24.0 \%, n=6$ trials, $P<0.05 ; 1 \mu \mathrm{M} \omega$-CgTX with G10: $117.2 \pm 13.7 \%$, $n=5$ trials, $P<0.01 ; 1 \mu \mathrm{M}$ NNC55-0396 with G10: 130.5 $\pm 21.9 \%, n=6$ trials, $P<0.05$ ). The application of $2 \mathrm{mM}$ EGTA with $10 \mathrm{mM}$ glucose also suppressed the amount of acyl- and desacyl-ghrelin secretion (Fig. 7C; acyl-ghrelin: 2 mM EGTA with G10: $88.7 \pm 13.1 \%, n=5$ trials, $P<0.01$ and desacyl-ghrelin: 2 mM EGTA with G10: $68.8 \pm 10.3 \%$, $n=6$ trials, $P<0.01)$. These results suggest that $\mathrm{L}-, \mathrm{N}-$, and T-type voltage-dependent $\mathrm{Ca}^{2+}$ channels induce $\left[\mathrm{Ca}^{2+}\right]_{\mathrm{i}}$ influx, which ultimately leads to ghrelin secretion from MGN3-1 cells.

\section{Discussion}

Increases in glucose concentrations cause the stimulation of various gastrointestinal hormones, including glucagonlike peptide 1 and insulin (Drucker 2006, 2007, Ashcroft \& Rorsman 2013). Glucose is believed to act principally to
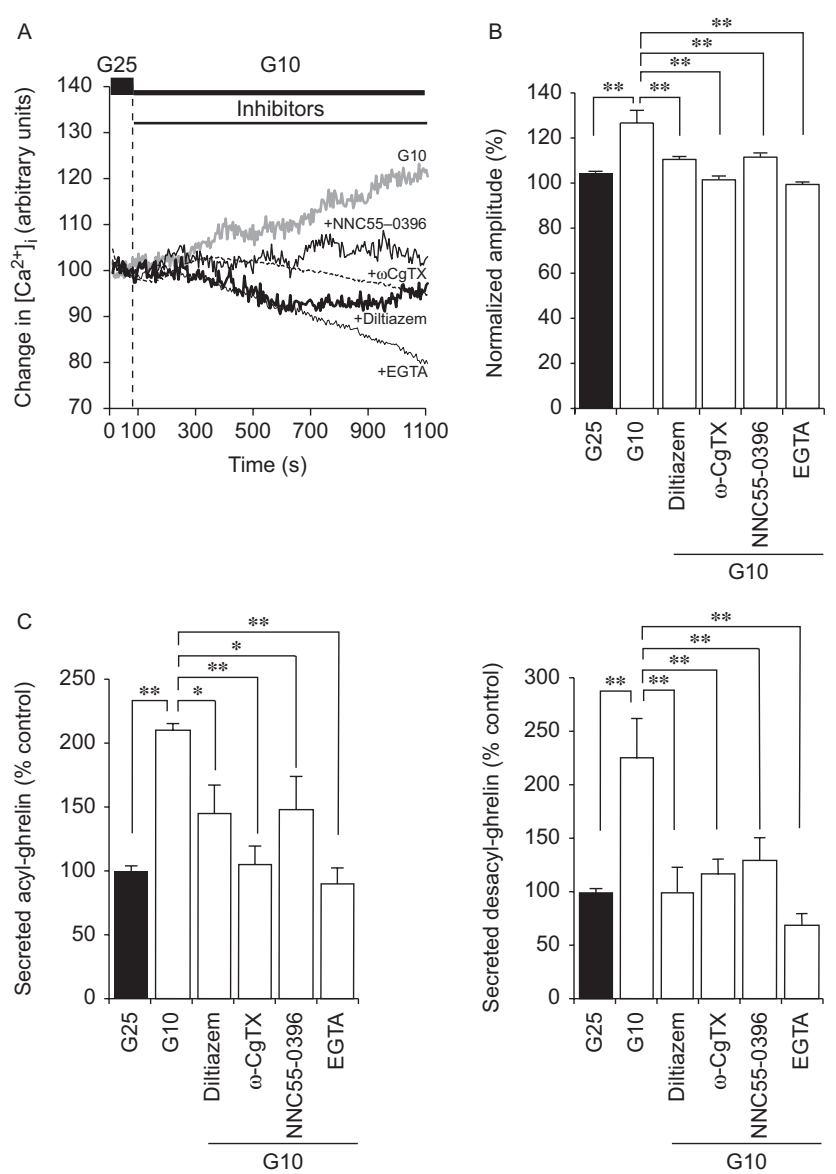

Figure 7

Effect of voltage-dependent $\mathrm{Ca}^{2+}$ channel blocker on ghrelin secretion from MGN3-1 cells. (A) Typical time course showing $\left[\mathrm{Ca}^{2+}\right]_{i}$ changes during the application of $10 \mathrm{mM}$ glucose with either $1 \mu \mathrm{M}$ diltiazem, $1 \mu \mathrm{M}$ $\omega$-conotoxin ( $\omega$-CgTX), $1 \mu$ M NNC55-0396, or 2 mM EGTA to MGN3-1 cells. Stimuli were applied at the times indicated by the dotted line. Basal fluorescence intensity was normalized to 100 . (B) Diltiazem, $\omega$-CgTX, NNC55-0396, and EGTA decreased the amplitude of the $\left[\mathrm{Ca}^{2+}\right]_{i}$ increases as compared to $10 \mathrm{mM}$ glucose alone. Normalized amplitude was calculated from the peak amplitude induced by various stimuli. Data are shown as means \pm S.E.M. ( $n=$ at least 25 cells in each condition). (C) The amount of secreted acyl- (left) and desacyl-ghrelin (right) after the application of either $1 \mu \mathrm{M}$ diltiazem, $1 \mu \mathrm{M} \omega$-CgTX, $1 \mu \mathrm{M}$ NNC55-0396, or 2 mM EGTA with $10 \mathrm{mM}$ glucose as measured by ELISA. Data are shown as means \pm S.E.M. ( $n=$ at least five trials in each condition). ${ }^{*} P<0.05$ and $* * P<0.01$.

stimulate ATP synthesis by initiating the closure of $\mathrm{K}_{\mathrm{ATP}}$ channels (Aguilar-Bryan \& Bryan 1999), the depolarization of plasma membrane, and $\mathrm{Ca}^{2+}$ influx (Safayhi et al. 1997). In the present study, we found that overexpressing a closed form of the Kir6.2 subunit or the $\mathrm{K}_{\mathrm{ATP}}$ channel blocker TB inhibited a $10 \mathrm{mM}$ glucose-induced $\left[\mathrm{Ca}^{2+}\right]_{\mathrm{i}}$ increase in novel ghrelin-secreting cell line MGN3-1 cells (Figs $2 \mathrm{~B}$ and $5 \mathrm{D}$ ), whereas the application of the $\mathrm{K}_{\mathrm{ATP}}$ channel opener $\mathrm{DZ}$ also inhibited $10 \mathrm{mM}$ glucose-induced $\left[\mathrm{Ca}^{2+}\right]_{i}$ increase. This complex phenomenon may be

Published by Bioscientifica Ltd 
explained by the hypothesis that moderate $\mathrm{K}_{\mathrm{ATP}}$ channel opening is required for ghrelin secretion from MGN3-1 cells. We speculate that the $\mathrm{K}_{\mathrm{ATP}}$ channels in MGN3-1 cells are opened a moderate amount in $10 \mathrm{mM}$ glucose. In other words, $\mathrm{K}_{\mathrm{ATP}}$ channels are closed in $25 \mathrm{mM}$ glucose but opened in $5 \mathrm{mM}$ glucose. Therefore, the application of a $\mathrm{K}_{\text {ATP }}$ channel opener or blocker in $10 \mathrm{mM}$ glucose disturbs the moderate $\mathrm{K}_{\mathrm{ATP}}$ channel opening, which leads to an inhibition of the $\left[\mathrm{Ca}^{2+}\right]_{\mathrm{i}}$ increase and ghrelin secretion. Furthermore, the closed $\mathrm{K}_{\mathrm{ATP}}$ channels in $25 \mathrm{mM}$ glucose are slightly opened by a low concentration of $\mathrm{DZ}$, and the opened $\mathrm{K}_{\mathrm{ATP}}$ channels in $5 \mathrm{mM}$ glucose are slightly closed by a low concentration of $\mathrm{TB}$, which induces a moderate $\mathrm{K}_{\mathrm{ATP}}$ channel opening for ghrelin secretion (Fig. 6). A previous study has shown that the $\mathrm{K}_{\mathrm{ATP}}$ channel modulators had little effect on ghrelin secretion in the ghrelin-secreting primary cells in vitro (Sakata et al. 2012). The application of $\mathrm{K}_{\mathrm{ATP}}$ channel modulators to MGN3-1 cells at a concentration two orders of magnitude lower than that study enabled us in the present study to pinpoint intermediate $\mathrm{K}_{\mathrm{ATP}}$ channel activity. In fact, when we applied high concentrations of $\mathrm{K}_{\mathrm{ATP}}$ channel modulators to the MGN3-1 cells, the $\mathrm{K}_{\mathrm{ATP}}$ channel modulators had little effect on $\left[\mathrm{Ca}^{2+}\right]_{\mathrm{i}}$ increase and ghrelin secretion (Figs 5 and 6).

Similar to the present results for ghrelin secretion, glucagon secretion has been shown to occur only within a narrow glucose level window in primary cultured pancreatic $\alpha$ cells in vitro (MacDonald et al. 2007). Cooperative interactions between voltage-dependent $\mathrm{N}$ - and T-type $\mathrm{Ca}^{2+}$ channels and $\mathrm{K}_{\text {ATP }}$ channels are implicated in that narrow window. In mouse pancreatic $\alpha$ cells, $K_{\text {ATP }}$ channels are involved in the activation of low-voltage-dependent T-type $\mathrm{Ca}^{2+}$ channels at low glucose concentrations. Opening of the T-type $\mathrm{Ca}^{2+}$ channels induces membrane depolarization and then activates high-voltage-dependent $\mathrm{N}$-type $\mathrm{Ca}^{2+}$ and $\mathrm{Na}^{+}$ channels. N-type $\mathrm{Ca}^{2+}$ channel-dependent $\left[\mathrm{Ca}^{2+}\right]_{\mathrm{i}}$ influx is known to induce glucagon secretion (Gopel et al. 2000, Gromada et al. 2007, MacDonald et al. 2007). In the present study, we found that the inhibitors of L-, N-, or T-type voltage-dependent $\mathrm{Ca}^{2+}$ channels suppressed both $\left[\mathrm{Ca}^{2+}\right]_{\mathrm{i}}$ influx and ghrelin secretion (Fig. 7). Therefore, similar to pancreatic $\alpha$ cells, cooperative interactions between voltage-dependent L-, $\mathrm{N}$-, and T-type $\mathrm{Ca}^{2+}$ channels and $\mathrm{K}_{\mathrm{ATP}}$ channels could create the narrow glucose level window. Further study is needed to clarify how $\mathrm{Ca}^{2+}$ channels regulate ghrelin secretion in that narrow window.

Ghrelin (amino acids 24-51) is generated by posttranslational processing of the 117 amino acid preproghrelin precursor protein by prohormone convertase $1 / 3$ (Romero et al. 2010). The presence of an eight-carbon fatty acid chain by the enzyme ghrelin$\mathrm{O}$-acyl-transferase on the serine 3 residue of acyl-ghrelin is required for the activation of the $\mathrm{GH}$ secretagogue receptor (Gutierrez et al. 2008). In contrast, desacylghrelin has no eight-carbon fatty acid chain on the serine 3 residue (Kojima et al. 1999). This presents difficulties in directly labeling ghrelin with FPs. We developed several hormones fused to FPs (i.e., BDNF-Venus, rat tPA-GFP, and rat GH-GFP) that co-localized with ghrelincontaining vesicles (data not shown). We found that BDNF-Venus showed the highest co-localization efficiency with acyl-ghrelin-positive vesicles in MGN3-1 cells, as revealed by the specific anti-acyl-ghrelin antibody and confocal microscopy (Fig. 3A). Therefore, we used BDNFVenus as an alternative marker for visualizing endogenous ghrelin secretion. In contrast to acyl-ghrelin, desacylghrelin has been described as a functional antagonist of acyl-ghrelin action (Cassoni et al. 2001, Thompson et al. 2004). Because the receptor for desacyl-ghrelin has not yet been identified (Hosoda et al. 2000), the function of desacyl-ghrelin still needs to be elucidated.

Plasma ghrelin concentration increases before meals and decreases after meals in humans and rats (Ariyasu et al. 2001, Cummings et al. 2001, Tolle et al. 2002). Recent studies have shown that water absorption and occlusion of the pylorus of stomach had little effect on plasma ghrelin concentration changes in rodents (Tschop et al. 2000, Williams et al. 2003), which suggests that gastric distension is not involved in the decrease in plasma ghrelin concentrations after meals. In addition, intra-gastric infusion of glucose in pylorus-occlusion rats did not reduce plasma ghrelin concentrations. Thus, absorbed nutrients (i.e., glucose, amino acids, and fatty acids) are involved in the regulation of plasma ghrelin concentrations. In fact, oral or i.v. administration of glucose has been shown to reduce plasma ghrelin concentrations (Ariyasu et al. 2002, McCowen et al. 2002, Shiiya et al. 2002, Nakai et al. 2003, Williams et al. 2003, Broglio et al. 2004). Consistent with these in vivo studies, in the present study, we found that low glucose induced $\left[\mathrm{Ca}^{2+}\right]_{\mathrm{i}}$ increase and ghrelin secretion in MGN3-1 cells, whereas high glucose did not. Therefore, our in vitro results help elucidate the mechanism of ghrelin secretion in vivo.

In conclusion, we used mouse ghrelin-secreting MGN3-1 cells to elucidate the molecular mechanisms of glucose-induced ghrelin secretion in vitro. In particular, we revealed that $\mathrm{K}_{\mathrm{ATP}}$ channels were expressed in MGN3-1 cells and mediated low glucose-induced ghrelin secretion.

Published by Bioscientifica Ltd 
Because ghrelin is an important hormone for regulating appetite, the modulation of $\mathrm{K}_{\mathrm{ATP}}$ channel activity in ghrelin-secreting X/A-like cells could prevent glucose intolerance and thereby provide a potential therapeutic application to counteract the progression of obesity or type 2 diabetes mellitus.

\section{Declaration of interest}

The authors declare that there is no conflict of interest that could be perceived as prejudicing the impartiality of the research reported.

\section{Funding}

This work was funded in part by a Grant-in-Aid for Science Research from the Ministry of Education, Culture, Sports, Science and Technology of Japan (grant numbers 24590350, 25350970, and 26460289), by the Pharmacological Research Foundation, Tokyo, and by the Takeda Science Foundation.

\section{Acknowledgements}

The authors thank Dr Hiroshi Iwakura for kindly providing us with the MGN3-1 cells and Dr Hideki Abe, Moemi Kishimoto, and Taichi Kamiya for their helpful comments and technical assistance.

\section{References}

Aguilar-Bryan L \& Bryan J 1999 Molecular biology of adenosine triphosphate-sensitive potassium channels. Endocrine Reviews 20 101-135. (doi:10.1210/edrv.20.2.0361)

Aoki R, Kitaguchi T, Oya M, Yanagihara Y, Sato M, Miyawaki A \& Tsuboi T 2010 Duration of fusion pore opening and the amount of hormone released are regulated by myosin II during kiss-and-run exocytosis. Biochemical Journal 429 497-504. (doi:10.1042/BJ20091839)

Ariyasu H, Takaya K, Tagami T, Ogawa Y, Hosoda K, Akamizu T, Suda M, Koh T, Natsui K, Toyooka S et al. 2001 Stomach is a major source of circulating ghrelin, and feeding state determines plasma ghrelin-like immunoreactivity levels in humans. Journal of Clinical Endocrinology and Metabolism 86 4753-4758. (doi:10.1210/jcem.86.10.7885)

Ariyasu H, Takaya K, Hosoda H, Iwakura H, Ebihara K, Mori K, Ogawa Y, Hosoda K, Akamizu T, Kojima M et al. 2002 Delayed short-term secretory regulation of ghrelin in obese animals: evidenced by a specific RIA for the active form of ghrelin. Endocrinology 143 3341-3350. (doi:10.1210/en.2002-220225)

Ashcroft FM \& Rorsman P $2013 \mathrm{~K}_{\mathrm{ATP}}$ channels and islet hormone secretion: new insights and controversies. Nature Reviews. Endocrinology 9 660-669. (doi:10.1038/nrendo.2013.166)

Broglio F, Gottero C, Prodam F, Destefanis S, Gauna C, Me E, Riganti F, Vivenza D, Rapa A, Martina V et al. 2004 Ghrelin secretion is inhibited by glucose load and insulin-induced hypoglycaemia but unaffected by glucagon and arginine in humans. Clinical Endocrinology 61 503-509. (doi:10.1111/j.1365-2265.2004.02121.x)

Cassoni P, Papotti M, Ghe C, Catapano F, Sapino A, Graziani A, Deghenghi R, Reissmann T, Ghigo E \& Muccioli G 2001 Identification, characterization, and biological activity of specific receptors for natural (ghrelin) and synthetic growth hormone secretagogues and analogs in human breast carcinomas and cell lines. Journal of Clinical Endocrinology and Metabolism 86 1738-1745. (doi:10.1210/jcem.86.4.7402)
Cummings DE, Purnell JQ, Frayo RS, Schmidova K, Wisse BE \& Weigle DS 2001 A preprandial rise in plasma ghrelin levels suggests a role in meal initiation in humans. Diabetes 50 1714-1719. (doi:10.2337/diabetes. 50.8.1714)

Drucker DJ 2006 The biology of incretin hormones. Cell Metabolism 3 153-165. (doi:10.1016/j.cmet.2006.01.004)

Drucker DJ 2007 The role of gut hormones in glucose homeostasis. Journal of Clinical Investigation 117 24-32. (doi:10.1172/JCI30076)

Foster-Schubert KE, Overduin J, Prudom CE, Liu J, Callahan HS, Gaylinn BD, Thorner MO \& Cummings DE 2008 Acyl and total ghrelin are suppressed strongly by ingested proteins, weakly by lipids, and biphasically by carbohydrates. Journal of Clinical Endocrinology and Metabolism 93 1971-1979. (doi:10.1210/jc.2007-2289)

Gopel SO, Kanno T, Barg S, Weng XG, Gromada J \& Rorsman P 2000 Regulation of glucagon release in mouse $\alpha$-cells by $\mathrm{K}_{\mathrm{ATP}}$ channels and inactivation of TTX-sensitive $\mathrm{Na}^{+}$channels. Journal of Physiology $\mathbf{5 2 8}$ 509-520. (doi:10.1111/j.1469-7793.2000.00509.x)

Gromada J, Franklin I \& Wollheim CB $2007 \alpha$-Cells of the endocrine pancreas: 35 years of research but the enigma remains. Endocrine Reviews 28 84-116. (doi:10.1210/er.2006-0007)

Gutierrez JA, Solenberg PJ, Perkins DR, Willency JA, Knierman MD, Jin Z, Witcher DR, Luo S, Onyia JE \& Hale JE 2008 Ghrelin octanoylation mediated by an orphan lipid transferase. PNAS 105 6320-6325. (doi:10.1073/pnas.0800708105)

Hosoda H, Kojima M, Matsuo H \& Kangawa K 2000 Ghrelin and des-acyl ghrelin: two major forms of rat ghrelin peptide in gastrointestinal tissue. Biochemical and Biophysical Research Communications 279 909-913. (doi:10.1006/bbrc.2000.4039)

Iwakura H, Li Y, Ariyasu H, Hosoda H, Kanamoto N, Bando M, Yamada G, Hosoda K, Nakao K, Kangawa K et al. 2010 Establishment of a novel ghrelin-producing cell line. Endocrinology 151 2940-2945. (doi:10.1210/en.2010-0090)

Iwakura H, Ariyasu H, Hosoda H, Yamada G, Hosoda K, Nakao K, Kangawa K \& Akamizu T 2011 Oxytocin and dopamine stimulate ghrelin secretion by the ghrelin-producing cell line, MGN3-1 in vitro. Endocrinology 152 2619-2625. (doi:10.1210/en.2010-1455)

Janssen S, Laermans J, Iwakura H, Tack J \& Depoortere I 2012 Sensing of fatty acids for octanoylation of ghrelin involves a gustatory G-protein. PLOS ONE 7 e40168. (doi:10.1371/journal.pone.0040168)

Kamegai J, Tamura H, Shimizu T, Ishii S, Sugihara H \& Oikawa S 2001 Regulation of the ghrelin gene: growth hormone-releasing hormone upregulates ghrelin mRNA in the pituitary. Endocrinology 142 4154-4157. (doi:10.1210/endo.142.9.8492)

Kitaguchi T, Oya M, Wada Y, Tsuboi T \& Miyawaki A 2013 Extracellular calcium influx activates adenylate cyclase 1 and potentiates insulin secretion in MIN6 cells. Biochemical Journal 450 365-373. (doi:10.1042/ BJ20121022)

Kojima M, Hosoda H, Date Y, Nakazato M, Matsuo H \& Kangawa K 1999 Ghrelin is a growth-hormone-releasing acylated peptide from stomach. Nature 402 656-660. (doi:10.1038/45230)

Koster JC, Remedi MS, Flagg TP, Johnson JD, Markova KP, Marshall BA \& Nichols CG 2002 Hyperinsulinism induced by targeted suppression of $\beta$ cell $\mathrm{K}_{\mathrm{ATP}}$ channels. PNAS 99 16992-16997. (doi:10.1073/pnas. 012479199)

MacDonald PE, De Marinis YZ, Ramracheya R, Salehi A, Ma X, Johnson PR, Cox R, Eliasson L \& Rorsman P 2007 A K $\mathrm{ATP}_{\mathrm{TP}}$ channel-dependent pathway within $\alpha$ cells regulates glucagon release from both rodent and human islets of Langerhans. PLoS Biology 5 e143. (doi:10.1371/journal. pbio.0050143)

Masuda Y, Tanaka T, Inomata N, Ohnuma N, Tanaka S, Itoh Z, Hosoda H, Kojima M \& Kangawa K 2000 Ghrelin stimulates gastric acid secretion and motility in rats. Biochemical and Biophysical Research Communications 276 905-908. (doi:10.1006/bbrc.2000.3568)

McCowen KC, Maykel JA, Bistrian BR \& Ling PR 2002 Circulating ghrelin concentrations are lowered by intravenous glucose or

Published by Bioscientifica Ltd 
hyperinsulinemic euglycemic conditions in rodents. Journal of Endocrinology 175 R7-R11. (doi:10.1677/joe.0.175R007)

McTaggart JS, Clark RH \& Ashcroft FM 2010 The role of the $\mathrm{K}_{\text {ATP }}$ channel in glucose homeostasis in health and disease: more than meets the islet. Journal of Physiology 588 3201-3209. (doi:10.1113/jphysiol.2010. 191767)

Mori R, Ikematsu K, Kitaguchi T, Kim SE, Okamoto M, Chiba T, Miyawaki A, Shimokawa I \& Tsuboi T 2011 Release of TNF- $\alpha$ from macrophages is mediated by small GTPase Rab37. European Journal of Immunology $\mathbf{4 1}$ 3230-3239. (doi:10.1002/eji.201141640)

Nagaya N \& Kangawa K 2003 Ghrelin, a novel growth hormone-releasing peptide, in the treatment of chronic heart failure. Regulatory Peptides 114 71-77. (doi:10.1016/S0167-0115(03)00117-4)

Nagaya N, Kojima M \& Kangawa K 2006 Ghrelin, a novel growth hormonereleasing peptide, in the treatment of cardiopulmonary-associated cachexia. Internal Medicine 45 127-134. (doi:10.2169/internalmedicine. 45.1402)

Nakai Y, Hosoda H, Nin K, Ooya C, Hayashi H, Akamizu T \& Kangawa K 2003 Plasma levels of active form of ghrelin during oral glucose tolerance test in patients with anorexia nervosa. European Journal of Endocrinology 149 R1-R3. (doi:10.1530/eje.0.149R001)

Nakazato M, Murakami N, Date Y, Kojima M, Matsuo H, Kangawa K \& Matsukura S 2001 A role for ghrelin in the central regulation of feeding. Nature 409 194-198. (doi:10.1038/35051587)

Oya M, Suzuki H, Watanabe Y, Sato M \& Tsuboi T 2011 Amino acid taste receptor regulates insulin secretion in pancreatic $\beta$-cell line MIN6 cells. Genes to Cells 16 608-616. (doi:10.1111/j.1365-2443. 2011.01509.x)

Oya M, Kitaguchi T, Yanagihara Y, Numano R, Kakeyama M, Ikematsu K \& Tsuboi T 2013a Vesicular nucleotide transporter is involved in ATP storage of secretory lysosomes in astrocytes. Biochemical and Biophysical Research Communications 438 145-151. (doi:10.1016/j.bbrc.2013. 07.043)

Oya M, Kitaguchi T, Pais R, Reimann F, Gribble F \& Tsuboi T $2013 b$ The G protein-coupled receptor family C group 6 subtype A (GPRC6A) receptor is involved in amino acid-induced glucagon-like peptide- 1 secretion from GLUTag cells. Journal of Biological Chemistry $\mathbf{2 8 8}$ 4513-4521. (doi:10.1074/jbc.M112.402677)

Quesada I, Tuduri E, Ripoll C \& Nadal A 2008 Physiology of the pancreatic $\alpha$-cell and glucagon secretion: role in glucose homeostasis and diabetes. Journal of Endocrinology 199 5-19. (doi:10.1677/JOE-08-0290)

Romero A, Kirchner H, Heppner K, Pfluger PT, Tschop MH \& Nogueiras R 2010 GOAT: the master switch for the ghrelin system? European Journal of Endocrinology 163 1-8. (doi:10.1530/EJE-10-0099)

Safayhi H, Haase H, Kramer U, Bihlmayer A, Roenfeldt M, Ammon HP, Froschmayr M, Cassidy TN, Morano I, Ahlijanian MK et al. 1997 L-type calcium channels in insulin-secreting cells: biochemical characterization and phosphorylation in RINm5F cells. Molecular Endocrinology 11 619-629. (doi:10.1210/mend.11.5.9922)

Sakata I, Park WM, Walker AK, Piper PK, Chuang JC, Osborne-Lawrence S \& Zigman JM 2012 Glucose-mediated control of ghrelin release from primary cultures of gastric mucosal cells. American Journal of Physiology. Endocrinology and Metabolism 302 1300-1310. (doi:10.1152/ajpendo. 00041.2012)

Sato M, Kitaguchi T, Numano R, Ikematsu K, Kakeyama M, Murata M, Sato K \& Tsuboi T 2012 The small GTPase Cdc 42 modulates the number of exocytosis-competent dense-core vesicles in PC12 cells. Biochemical and Biophysical Research Communications 420 417-421. (doi:10.1016/ j.bbrc.2012.03.010)

Seino S, Iwanaga T, Nagashima K \& Miki T 2000 Diverse roles of $\mathrm{K}_{\mathrm{ATP}}$ channels learned from Kir6.2 genetically engineered mice. Diabetes $\mathbf{4 9}$ 311-318. (doi:10.2337/diabetes.49.3.311)

Shiiya T, Nakazato M, Mizuta M, Date Y, Mondal MS, Tanaka M, Nozoe S, Hosoda H, Kangawa K \& Matsukura S 2002 Plasma ghrelin levels in lean and obese humans and the effect of glucose on ghrelin secretion. Journal of Clinical Endocrinology and Metabolism 87 240-244. (doi:10.1210/jcem.87.1.8129)

Suzuki M, Fujikura K, Inagaki N, Seino S \& Takata K 1997 Localization of the ATP-sensitive $\mathrm{K}^{+}$channel subunit Kir6.2 in mouse pancreas. Diabetes 46 1440-1444. (doi:10.2337/diab.46.9.1440)

Suzuki M, Fujikura K, Kotake K, Inagaki N, Seino S \& Takata K 1999 Immuno-localization of sulphonylurea receptor 1 in rat pancreas. Diabetologia 42 1204-1211. (doi:10.1007/s001250051293)

Takaya K, Ariyasu H, Kanamoto N, Iwakura H, Yoshimoto A, Harada M, Mori K, Komatsu Y, Usui T, Shimatsu A et al. 2000 Ghrelin strongly stimulates growth hormone release in humans. Journal of Clinical Endocrinology and Metabolism 85 4908-4911. (doi:10.1210/jcem.85. 12.7167)

Theander-Carrillo C, Wiedmer P, Cettour-Rose P, Nogueiras R, Perez-Tilve D, Pfluger P, Castaneda TR, Muzzin P, Schurmann A, Szanto I et al. 2006 Ghrelin action in the brain controls adipocyte metabolism. Journal of Clinical Investigation 116 1983-1993. (doi:10.1172/JCI25811)

Thompson NM, Gill DA, Davies R, Loveridge N, Houston PA, Robinson IC $\&$ Wells T 2004 Ghrelin and des-octanoyl ghrelin promote adipogenesis directly in vivo by a mechanism independent of the type 1a growth hormone secretagogue receptor. Endocrinology 145 234-242. (doi:10.1210/en.2003-0899)

Tolle V, Bassant MH, Zizzari P, Poindessous-Jazat F, Tomasetto C, Epelbaum J \& Bluet-Pajot MT 2002 Ultradian rhythmicity of ghrelin secretion in relation with $\mathrm{GH}$, feeding behavior, and sleep-wake patterns in rats. Endocrinology 143 1353-1361. (doi:10.1210/endo.143. 4.8712)

Tschop M, Smiley DL \& Heiman ML 2000 Ghrelin induces adiposity in rodents. Nature 407 908-913. (doi:10.1038/35038090)

Tsuboi T, Ravier MA, Parton LE \& Rutter GA 2006 Sustained exposure to high glucose concentrations modifies glucose signaling and the mechanics of secretory vesicle fusion in primary rat pancreatic $\beta$-cells. Diabetes 55 1057-1065. (doi:10.2337/diabetes.55.04.06.db05-1577)

Williams DL, Cummings DE, Grill HJ \& Kaplan JM 2003 Meal-related ghrelin suppression requires postgastric feedback. Endocrinology 144 2765-2767. (doi:10.1210/en.2003-0381)

Received in final form 16 April 2015

Accepted 5 May 2015 http://joe.endocrinology-journals.org

DOI: $10.1530 /$ JOE-15-0090
(C) 2015 Society for Endocrinology Printed in Great Britain
Published by Bioscientifica Ltd. 